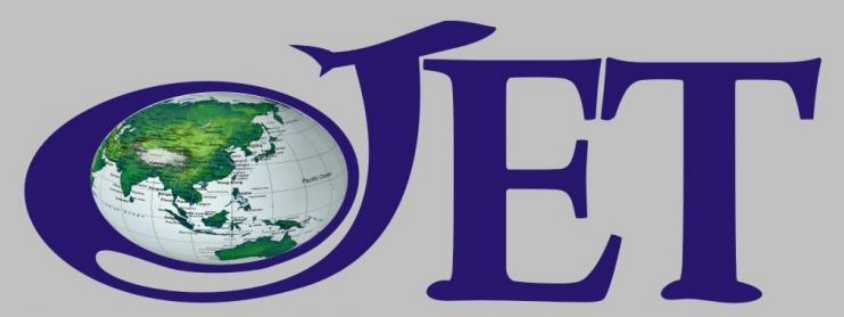

Journal of English Teaching a

triannual

publication

on the study of

English Language Teaching

Volume 1, Number 1, February 2011

\title{
Using Short Stories to Teach Language Skills
}

\author{
Parlindungan Pardede \\ Christian University of Indonesia \\ Jakarta, Indonesia \\ e-mail: parlpard2010@gmail.com
}

\begin{abstract}
The notion that the main objective of EFL teaching is to help students to communicate fluently in the target language cause many teachers still believe that an EFL class should focus on mastering linguistic elements only. However, recent trend in EFL teaching indicates the necessity of integrating literature because of its rich potential to provide an authentic model of language use. Among literary genres, short stories seem to be the most suitable choice for this due to its potential to help students enhance the four skills-listening, speaking, reading and writing-more effectively because of the motivational benefit embedded in the stories. The purpose of this article is to familiarize EFL instructors with the effectiveness of using short stories in EFL instruction. After presenting criteria for selecting a short story, discussion is focused on how to exploit a short story for enhancing students' language skills.
\end{abstract}

Keywords: literature, short story, language skills 


\section{Introduction}

In the nineteenth century, the Grammar Translation Method (GTM) predominated ESL/EFL teaching. During the era, translating literary texts from the second/foreign language to the students' native language was one of the main learning activities. Therefore, literary works were a notable source of material in ESL/EFL teaching (Prodromou, 2000). But when GTM was replaced by the Structuralism Approach in 1960s to the end of 1970s, literature was no longer used. Structuralism was concerned with correctness of grammatical form and not with content or interpretation of the written word or style. In other words, teaching a foreign language was regarded as a matter of linguistics. Then, when the Direct Method, the Audiolingualism, Community Language Learning, Suggestopedia, the Silent Way, Total Physical Response, and the Natural Approach successively dominated ESL/EFL teaching, literature was not utilized. Later on and with the appearance of the Communicative Approach in the late 70`s and very early 80 `s, literature was also ignored. The tendency in the EFL classrooms was to teach "usable, practical" contents. Thus, literary works had no place in the curriculum. During this period most EFL courses were mainly aimed to enable the students to communicate orally. Consequently, dialogues dominated the curriculum.

However, since the 1980s the situation changed quite radically when literature has found its way back into the teaching of EFL. But, different from the way it was used with the GTM, the current use of literary works in $\mathrm{ESL} / \mathrm{EFL}$ classes is to improve communicative competence and providing "a springboard for the development of critical thinking and aesthetic appreciation" (Bretz, 1990: 335-338) and create students' awareness on the culture and society of the relevant country. Since then, literature is undergoing an extensive reconsideration within the language teaching profession. Literary works use in ESL/EFL classes has attracted more interest among teachers, and more and more studies on how to use literature in EFL/ESL classes are conducted. The results of some studies, like those of Lazar (1993), Cook (1994), and Shanahan (1997), for instances, strongly recommend the integration of literary texts into the SL/FL curriculum. Many writings on this subject advocate a contentfocused curriculum that includes literature (Kramsch, 1993; Liddicoat \& Crozet 2000).

Theoretically, using of literature in language teaching is very advantageous for it offers four benefits: authentic material, cultural enrichment, language advancement, and personal growth (Collie \& Slater, 1991). This is in line with Erkaya (2005) who notes four benefits of using of short stories to teach ESL/EFL, i.e. motivational, literary, cultural and higher-order thinking benefits.

First of all, literary texts can be more beneficial than informational materials in stimulating the acquisition process as they provide authentic 
contexts for processing new language. Literary texts expose learners to fresh themes and unexpected language. In this sense, 'a literary text is authentic text, real language in context, to which we can respond directly" (Brumfit and Carter, 1986, p. 15). This quality appears to make literature suitable and valuable to language teaching in many contexts and cultures. In addition, since literary texts contain language intended for native speakers, literature stands as a model for language learners to become familiar with different forms and conventions (Collie and Slater, 1991, p. 4; Ur, 1996, p. 201).

Second, containing real examples of grammatical structures and vocabulary items, the literary texts raise learners' awareness of the range of the target language and advance their competence in all language skills (Povey, 1967). Literary texts are not written for the specific purpose of teaching. Instead, they deal with "things which mattered to the author when he wrote them" (Maley, 1989, p. 12). So, compared to the language samples in the textbooks, the language is far richer and more varied. Many genuine features of the written language such as "the formation and function of sentences, the variety of possible structures, and the different ways of connecting ideas" are presented at many levels of difficulty (Collie and Slater, 1994, p. 5). By assigning learners to explore the literary language, they have been at the same time been encouraged to think about the norms of the language use (Widdowson, 1975, cited in Lazar, 1993, p. 18). Learners are encouraged to familiarize themselves with different language uses, forms or conventions. Such exposure is essential for the learners especially for their language development. Thus, they can appreciate the richness and variety of the language and become more sensitive to the features of it.

Third, using literature in language teaching has the advantage of providing cultural information about the target language. Literary texts increase foreign language learners' insight into the country and the people whose language is being learnt (Collie and Slater, 1991), which fosters learners' ability to interpret discourse in different social and cultural target language contexts (Savvidou, 2004). By reading literary works, learners learn to see a world through another's eyes, observing human values and a different kind of living, and discovering that others living in very different societies. They will understand and become broadly aware of the social, political, historical, cultural events happening in a certain society. Through literature, learners can deepen their cultural understanding.

Finally, since literature enables students to understand and appreciate other cultures, societies and ideologies different from their own, it encourages personal growth and intellectual development (Carter and Long, 1991, pp. 2-4). In accordance with these ideas, Littlewood (2000) emphasizes the importance of the use of literature in EFL classes by arguing that: 
A major problem of language teaching in the classroom is the creation of an authentic situation for language. All language classrooms, especially those outside the community of native speakers, are isolated from the context of events and situations which produce natural language. Literature can overcome this problem because, in literary works, language creates its own context. The actual situation of the reader becomes immaterial as he or she looks on the events created by language. These events create, in turn, a context of situation for the language of the book and enable it to transcend the artificial classroom situation (p. 179).

Based on these ideas, it is obvious that literary works undoubtedly enable students to understand the language better by providing them with real world experiences, relationships between society and people where the target language is spoken, even if they are fictions.

\section{Why Short Stories?}

Despite its benefits for students, some objections are always raised against the use of literature in public schools due to overcrowded classes, overloaded syllabus and limited time-some problems commonly met in elementary to high public schools in almost all developing countries. First, the deviated and figurative language of poetry necessitates very long time to grasp. Second, the length of novel will make it difficult for such classes to finish. Finally, drama can be used in classes, but it will be difficult to act out a play in crowded classes within limited course hours. Considering these objections, it is obvious that among literary forms, short-story, which is defined by Poe (as cited in Abrams, 1970, p. 158) "as a narrative that can be read at one sitting of from one-half hour to two hours, and that is limited to 'a certain unique or single effect,' to which every detail is subordinate", seems to be the most suitable one to use in public schools. Since it is short, and aims at giving a 'single effect', there is usually one plot, a few characters; there is no detailed description of setting. So, it is easy for the students to follow the story line of the work.

The idea that short stories are the most suitable literary genre to use in English teaching due to its shortness is supported by Hirvela and Boyle's (1988) study on adult Hong Kong Chinese students' attitudes towards four genres of literary texts (short story, novel, poetry and drama) indicated short stories as the genre that is less feared and the second most enjoyed (43\%; the novel is the most enjoyed with $44 \%$ ), since short stories are easy to finish and definite to understand. The idea is also in line with Collie and Slater (1991, p. 196) when they list four advantages of using short stories for language teachers. First, short stories are practical as their length is long enough to cover entirely in one or two class sessions. Second, short stories are not complicated for 
students to work with on their own. Third, short stories have a variety of choice for different interests and tastes. Finally, short stories can be used with all levels (beginner to advance), all ages (young learners to adults) and all classes (morning, afternoon, or evening classes).

The idea that short stories are very suitable to use in English teaching is supported by Pardede's (2010) research findings on the interest, perceptions, and the perceived needs of the students of the English teachers training of Christian University of Indonesia towards the incorporation of short story in language skills classes. The research revealed that a majority of the respondents basically found short stories interesting to use both as materials for selfenjoyment and of as components language skill classes. Most of them also agreed or strongly agreed that the incorporation of short stories in language skills classes will help learners achieve better mastery of language skills. They even believed that English teacher candidates should master the skills of employing short stories to teach language skills. In addition, the statistical analysis revealed that the students' interest and perceptions were positively and significantly correlated, and both variables significantly affected each other.

\section{Choosing the Text}

The use of short-story in English teaching should be aimed to encourage the students to use what they have previously learnt. By doing this, the learning process will be student-centered. However, the teacher plays a great role. She/he must choose a suitable text to use in class, and should help her/his students understand the story with various activities.

In using short stories to teach English, story selection is indeed one of the most important roles of the teacher. Since the lengths of short-stories quite vary, choose a story short enough to handle within course hours. The shortness of the text is important for the students because they will see that they can read, understand and finish something in English, and it will give the students a feeling of achievement and self-confidence. Besides the length of the text, Hill (1994, p. 15) points out three other basic criteria of choosing the text: (1) the needs and abilities of the students; (2) the linguistic and stylistic level of the text; (3) the amount of background information required for a true appreciation of the material.

The importance of considering these criteria could be perceived by realizing that the vocabulary and sentence structure of the short-story to be studied must be suitable to the level of the students. The short-stories with archaic, slang, foreign words, and allusions, having sentences imitating the speech of a particular locality or ignorant people or foreigners should be avoided if the text is intended for students below intermediate level. Similarly, very long sentences are difficult for students to understand. As students will not understand these sentences and words, they will get bored and not read the 
work. Therefore, before giving the short-story, the teacher should decide the readability of the text.

In order to meet that readability criterion, using graded or simplified stories is possibly the most practical way. According to Ur (1996), “... the use of 'authentic' text with less proficient learners is often frustrating and counterproductive" (p. 150). Therefore, the use of simplified text with less proficient readers is highly suggested for the sake of suiting the texts with the level of students.

In addition to the previous criteria, Spack (1985) suggests the aspect of interest to be considered. According to him, it is important for the teacher to choose stories that would interest students that he/she most likes to read and teach, and that have been made into film to provide visual interpretation. McKay (2001, p. 322) and Rivers (1968, p. 230) point out that students read and enjoy a text if the subject-matter of the text is relevant to their life experience and interests.

\section{Short Stories and Language Skills Development}

Short stories allow teachers to teach the four skills to all levels of language proficiency. Murdoch (2002) indicates that "short stories can, if selected and exploited appropriately, provide quality text content which will greatly enhance ELT courses for learners at intermediate levels of proficiency" (p. 9). According to him, short stories could be very beneficial materials in ELT reinforcement by using them in learning activities such as, discussion, writing and acting out dialogues.

In the following sections, while showing how to exploit a short story to develop language skills, a series of activities is presented as a sample so that teachers get concrete ideas about how to use short stories in their EFL classrooms. A student-centered approach is presented in this sample. This approach allows more exploration of the short story, offers the students more opportunities to formulate their own ideas or feelings about the issue(s) as well as to improve their basic skills in the language learning process. To cater various learning styles, it is necessary to devise various kinds of tasks and activities. All of them are carried out in English to immerse students in an English-speaking environment.

\section{A. Reading}

Short stories are very useful in the trials to improve students' vocabulary and reading. The results of Lao and Krashen's (2000) study which compared the reading achievement between a group of students that read literary texts and a second group that read non-literary texts at a university in Hong Kong revealed that the group who read literary texts made better improvement in vocabulary and reading. Using A Long Walk Home (see the appendix), three 
activities can be conducted to help students to acquire more vocabulary. These activities are related to form, meaning, and use respectively.

1. Complete the word form chart below. The first word has been done for you. Remember that some words do not have all forms.

\begin{tabular}{|c|c|c|c|c|}
\hline Verb & Adverb & Participle & Noun & Adjective \\
\hline grow & - & growing & growth & - \\
\hline & & & & remote \\
\hline & hardly & & & \\
\hline & & & opportunity & \\
\hline immerse & & & & \\
\hline
\end{tabular}

There can be as many words as the teacher thinks necessary. However there should not too many words included in a short story so as not to make students lose interest in the activity. This activity helps students to learn more vocabulary, and it also teaches them how to use a dictionary.

2. Write the letter of the definition/synonym in column B that most closely matches each word/phrase in column A.

\begin{tabular}{|l|l|}
\hline \multicolumn{1}{|c|}{ A } & \multicolumn{1}{|c|}{ B } \\
\hline a. to spare & 1. appear; make an appearance; \\
\hline b. immersed & 2. lateness \\
\hline c. to show up & 3. free for other use \\
\hline d. tardiness & 4. engaged wholly or deeply; absorbed \\
\hline e. $\ldots$ & $5 . \ldots$ \\
\hline
\end{tabular}

In this activity, the words/phrases in column A come from the story students are reading. The definitions and/or synonyms provided in column B must match the meaning of the words/phrases in the context of the story to help students to understand how a different word/phrase can be used in the same context. 
3. Choose the word/phrase from column A in the previous activity that best fits each of the following sentences. You may need to add $-\mathrm{s}$ to a plural word or to a third person singular of a verb in the present tense, -ed to the past tense of regular verbs, -ing for present participle, etc.

a) She finally after we waited for her for two hours.

b) Johan was so in his that he did not realize morning had broken.

c) After finishing this homework, I have quite much time.

d) Mr. Moore looked angry when I entered the meeting room. But he finally excused my after I finished explaining why I was late.

In activity 3, students practice using the words they already understand the meanings of. Since "Bill" does not include a list of unknown words/phrases in bold and the words/phrases do not have explanation and/or synonyms on the footnote, teachers should add both. To motivate students do such activity, teacher may explain: "The list of words helps you go on reading without troubling yourself stopping for too long to look them up in a dictionary or thesaurus."

High-intermediate and advanced students also profit from literary texts. What they read gives them the opportunity to come up with their own insights and helps them speak the language in a more imaginative way. They become more creative since they are faced with their own point of view, that/those of the main character(s) of the story and those of their peers. According to Oster (1989), this process leads to critical thinking, by confirming, "Focusing on point of view in literature enlarges students' vision and fosters critical thinking by dramatizing the various ways a situation can be seen" (p. 85). This could happen because when students read, they interact with the text. By interacting with the text, they interpret what they read. By interpreting what they read, they can work toward speaking English more creatively.

\section{B. Writing}

Short story can be a powerful and motivating source for writing in ESL/EFL, both as a model and as subject matter. Short story as a model occurs when students' writing becomes closely similar to the original work or clearly imitates its content, theme, organization, and /or style. However, when student writing exhibits original thinking like interpretation or analysis, or when it emerges from, or is creatively stimulated by, the reading, literature serves as subject matter. In accordance with this, Oster (1989, p. 85) affirms that literature helps students to write more creatively. 
Teachers can create a variety of writing activities to help students to develop their writing skills. They can ask students to write dialogues or more complex writing activities if students have reached a high level of language proficiency. For example, if teachers bring to class A Long Walk Home, they can assign the following writing activities:

1. Write a dialogue between Jackson and his father that morning (paragraph one).

2. Paraphrase the last two paragraphs of the short story.

3. Write a book report or summarize the story in five to seven sentences, including the main character, setting, conflict, climax, and resolution.

4. Write one sentence on the theme of the story.

5. Write a paragraph to explain what you think Jackson has learned from that experience.

6. Write a review on the story.

7. Write an essay on what you like or dislike in the story.

Activities 1 and 2 are suitable for middle intermediate levels; activities 3 and 4 for upper intermediate levels; and activities 5, 6 and 7 for advanced levels.

\section{Speaking and Listening}

Short story can also be a powerful and motivating source for teaching both speaking and listening. Oral reading, dramatization, improvisation, roleplaying, reenactment, and discussion are some effective learning activities which center on a short story EFL classes can use for enhancing these two skills. Asking students to read story aloud can develop their speaking as well as listening skills. Moreover, it also leads to improving pronunciation.

The followings are some activities teachers can assign to develop students speaking skills by using short stories.

1. The students read the story aloud as a chain activity. The first student reads the first sentence. The second student takes the second sentence, the third student, third sentence, and so forth. Such activity will enhance students' pronunciation and fluency in an interesting way. It is suitable for elementary class.

2. In an upper intermediate class, the students retell the story as a chain activity in small groups. Each student will have a lot of opportunities to practice the relevant connectors or other discourse markers in a meaningful context. (They certainly should have been given a list of the connectors and discourse markers beforehand.) 
3. In an advanced class, the students are grouped into two groups. Using $A$ Long Walk Home, the first group is assigned to prepare arguments that the father's decision to punish himself is appropriate. Another group should prepare arguments that the decision is not appropriate.

4. An extending activity useful to develop students' speaking skill and to make students more involved in the story is role-play. This can be carried out by asking students to play the role of several characters, i.e. by instructing them the followings:

a. Imagine you are Jackson. Tell your partner (acting as his father) why you were late coming from the garage. Make sure you are convincing.

b. Suppose you are the receptionist of the garage in which Jackson took the car. Tell Jackson' father about the car.

To develop listening skill using a short story, teachers can do the followings:

1. Read the story out loud so students have the opportunity to listen to a native speaker of English (if at all possible); or

2. Play the story if a recording is available.

The activity can be carried out for fun or for students to find answers to questions given and explained to them before the listening activity starts. For students to understand the story when they listen to it for the first time, the questions can be based on literary structures, such as:

1. Who is the main character of A Long Walk Home?

2. Where/when does the story take place?

3. What is the problem (conflict) in the story?

4. How is the conflict resolved?

\section{Conclusion}

Since the objective of EFL teaching is to help students to communicate fluently in the target language, teachers should provide an authentic model of language use. To do it, she/he should focus not only on linguistic but also on literary and cultural elements. Since short stories offer these elements, they are highly beneficial to use in ESL/EFL teaching programs. However, the selection of short stories should be done in reference to the course objective, the learners' profile, and the story content in order to make the best of it. Since every teaching situation is unique, the use of one single piece of literature varies from classroom to classroom and from teacher to teacher. Like what the discussion in 
this paper shows, short stories can be used to provide different activities for reading, listening, writing and speaking classes. Short story creates a meaningful context to teach different language focuses and to improve the students' interpretative strategies. Last but not least, the same story may also serve for some other language focuses or skills such as vocabulary development.

\section{References}

Abrams, M.H. (1970). A glossary of literary term. New York: Rinehart.

Bocarro, J. (1997). A long walk home. In Canfield, J. (Ed.). Chicken soup for the soul. USA: HCI Books.

Bretz, M. L. (1990). Reaction: Literature and communicative competence: A springboard for the development of critical thinking and aesthetic appreciation. Foreign Language Annals, 23(4), 335-338.

Brumfit, C.J. \& Carter, R.A. (1986). Literature and language teaching. Oxford: Oxford University Press.

Carter, R., \& Long, M.N. (1991). Teaching literature. Harlow: Longman.

Collie, J., \& Slater, S. (1991). Literature in the language classroom. (5th ed.). Glasgow: Cambridge University Press.

Cook, G. (1994). Discourse and literature: The interplay of form and mind. Oxford: Oxford University Press.

Hill, Jeniffer. (1994). Using literature in language teaching. London: Macmillan.

Hirvela, A., \& Boyle, J. (1988). Literature courses and student attitudes. ELT Journal, 42, 179-184.

Kramsch, C. (1993). Context and culture in language teaching. Cambridge: Cambridge University Press.

Lazar, Gillian. (1993). Literature and language teaching. Cambridge: Cambridge University Press.

Liddicoat, A.J. and Crozet, C. (Eds.). (2000). Teaching languages, teaching cultures. Melbourne: Language Australia.

Littlewood, W. (2000). Literature in the school foreign-language course. In Brumfit, C.J. \& Carter, R.A. (Eds.) Literature and Language Teaching. Oxford: Oxford University Press.

Maley, A. (1989). Down from the pedestal: literature as a resource. In Brumfit, C.J. \& Carter, R.A. (Eds.), Literature and the learner: Methodological approaches (pp. 10-23). London: McMillan

McKay, S. L. (1986). Literature in the ESL classroom, London: Oxford University Press. 
(2001). Literature as content for ESL/EFL. Celce-Murcia (Ed.). Teaching English as a second or foreign language (3rd Edition) (pp. 319-332) Boston: Heinle and Heinle.

Oster, J. (1989). Seeing with different eyes: Another view of literature in the ESL Class. TESOL Quarterly, 23, 85-103

Pardede, P. (2010). Short stories use in language skills classes: Students' interest and perception. The Proceeding of the 4th International Seminar 2010: Bringing Linguistics and Literature into EFL Classrooms (pp. 117). Salatiga: Satya Wacana Christian University

Povey, J.F. (1967). Literature in TESOL programs: The language and the culture. TESOL Quarterly, 1,40-46.

Prodromou, L. (2000). Reason not the need: Shakespeare in ELT. IATEFL Issues, 156. Retrieved August 22, 2008, from: http://www. iatefl.org/archives/Texts/156Prodmorou

Rivers, W. M. (1981). Teaching foreign-language skills, (2nd ed.). Chicago and London: The University of Chicago Press.

Savvidou, C. (2004). "An Integrated Approach to the Teaching of Literature in the EFL Classroom." The Internet TESL Journal, 10 (12) Retrieved July, 2010, from http://iteslj.org/Techniques/Savvidou_Literature.html

Sell, R. D. (1995). Why is literature central? Review of English Language Teaching. 5 (1), 4-19.

Shanahan, D. (1997). Articulating the Relationship Between Language, Literature and Culture: Toward a New Agenda for Foreign Language Teaching and Research. The Modern Language Journal. 81, 2, 164-174.

Spack, R. (1985). Literature, reading, writing, and ESL: Bridging the gaps. TESOL Quarterly, 19, 703-725.

Ur, P. (1996). A Course in language teaching: Practice and theory. Cambridge: Cambridge University Press. 
Appendix

\section{A Long Walk Home}

(by: Jason Bocarro)

I grew up in the south of Spain in a little community called Estepona. I was 16 when one morning my father told me I could drive him into a remote village called Mijas, about 18 miles away, on the condition that I take the car in to be serviced at a nearby garage. Having just learned to drive and hardly ever having the opportunity to use the car, I readily accepted. I drove Dad into Mijas and promised to pick him up at 4 p.m., then drove to a nearby garage and dropped off the car. Because I had a few hours to spare, I decided to catch a couple of movies at a theatre near the garage. However, I became so immersed in the films that I completely lost track of time. When the last movie had finished, I looked down at my watch. It was six o'clock. I was two hours late.

I knew Dad would be angry if he found out I'd been watching movies. He'd never let me drive again. I decided to tell him that the car needed some repairs and that they had taken longer that had been expected. I drove up to the place where we had planned to meet and saw Dad waiting patiently on the corner. I apologized for being late and told him that I'd come as quickly as I could, but the car had needed some major repairs. I'll never forget the look he gave me.

"I'm disappointed that you feel you have to lie to me, Jackson."

"What do you mean? I'm telling the truth."

Dad looked at me again. "When you did not show up, I called the garage to ask if there were any problems, and they told me that you had not yet picked up the car. So you see, I know there were no problems with the car." A rush of guilt ran through me as I feebly confessed to my trip to the movie theater and the real reason for my tardiness. Dad listened intently as a sadness passed through him.

"I am angry, not with you but with myself. You see, I realize that I have failed as a father if after all these years you feel that you have to lie to me. I have failed because I have brought up a son who cannot even tell the truth to his 
own father, I'm going to walk home now and contemplate where I have gone wrong all these years".

"But Dad, its 18 miles to home. It's dark. You can't walk home."

My protests, my apologies and the rest of my utterances were useless. I had let my father down, and I was about to learn one of the most painful lessons of my life. Dad began walking along the dusty roads. I quickly jumped in the car and followed behind, hoping he would relent. I pleaded all the way, telling him how sorry I was, but he simply ignored me, continuing on silently, thoughtfully and painfully. For 18 miles I drove behind him, averaging about five miles per hour.

Seeing my father in so much physical and emotional pain was the most distressing and painful experience that I have ever faced. However, it was also the most successful lesson. I have never lied to him since. 